\title{
襲兒の音聲の聽取について
}

東京萄研學校

石井敎

\section{I 問題の成立}

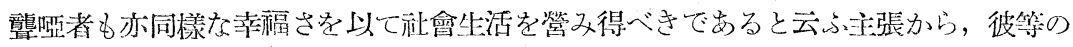
思想の理解及び表現の手段が，今や內外の轞哑學校を通じて㱠んど所謂手話法から口話

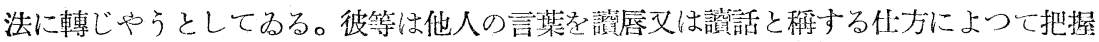
し，自らも音警を以て普通の言葉を柴り得るやらに教育されつ小ある。作し之等の力法

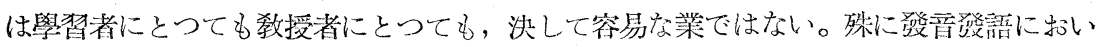
てさらである。恐らく全く殘聪索き先天性の犝兒つ墢する言葉を始めて聞いて理解出來 る者は極めて少いであらら。其程彼等の發音機能は未分化の爿態にあるものであつて， 之を最も迅速且つ正確に指導矯正する方法の確立は今日の緊急な問題でせる。

龍兒の中には，何等かの音を聽取出來る者が思ひの外多いのでまるが，此の殘㜇の度 の大いなる者程發音が巧であり，音質も遥かに美しいものが多い。殘聴と發昔との比例 的關係は，今直ちに之を數量的に示し得る材料は持たないが，日常萑察する所に上り， 殆えど確實な事實の樣である。此の事から直接に考へ及ぶことはより多く作意的に殘㯖 を發㱏指導に役立てると云ら事である。侀し之には偷如何なる殘聽の者に，如何なる方 法を以てする時，その發㱏指導への利胜性が最も大であるかを沈定しなければならぬ。 唯徒らに試ることは時と勞と空費するに過ぎないからでむる。かつる呚育仆の間題 に，多少とも貢献する事が出來れい゙，本賽驗の誠に素ひとずる所である。

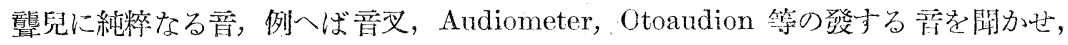
之が高さ强さの兩軸上における限界を求めて聽取範圍を決定することが，一般に行はれ

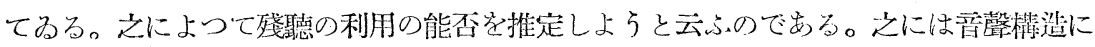
關する，諸種の心理學的，物理學的探究が，基礎を與へてるるのであるが，本實驗では

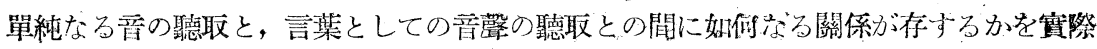
の襲兒についてしらべて見たいと考へたのである。之によつて，機城的の如们なる辛の

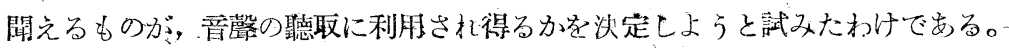

\section{II 實 驗 $\boldsymbol{A}$}

此の實驗に用ひた被驗者は，東京竴哑學校の中等部及び 初等部の坐徒 ‘2 名である。 之等は比較的よく聞えるものが多いが，何れも普通學級に屬するもので，此の他特に殘 
㯖の著しいものは，難聽學級と稱する特別の學級に編入されてるる。今の所之は三學級 ある。件し上記の被驗者の中にも後に見る如く難聽兒と見做される者むある。

さて之等の被驗者については豫め數回に亘つて $2 \mathrm{~A}$ Audiometer の檢查を行つてあつ て, 各個人の殘㯖がしらべてまる。此の檢查法及びその結果の整理の仕方については, かつて報告したことがあるので，此處には再記しない。要するに，此の器槭では C c $\mathrm{c}^{1} \mathrm{c}^{2} \mathrm{c}^{3} \mathrm{c}^{4} \mathrm{c}^{5} \mathrm{c}^{6}$ の 8 種の純粹な音について, 正常者の何パーセントの残聽を有するか と云ふ事が算出出來るやらになつてるるのである。上の 22 名の者につき，左右何れか 秀れた方の耳の殘聽を示すと第 1 圖の如くである。太い線のものは $50 \%$ 以上の殘聽で

\section{第 1 圖}

Wt. Kw. Kz. Kd. Ok. Jy. Kzm.Kr. Bt.Kdm.Mm.Fz. Nk. Ym. Nz. Tk. It. Ymg.Hr.Ymg.Ith, Iz.

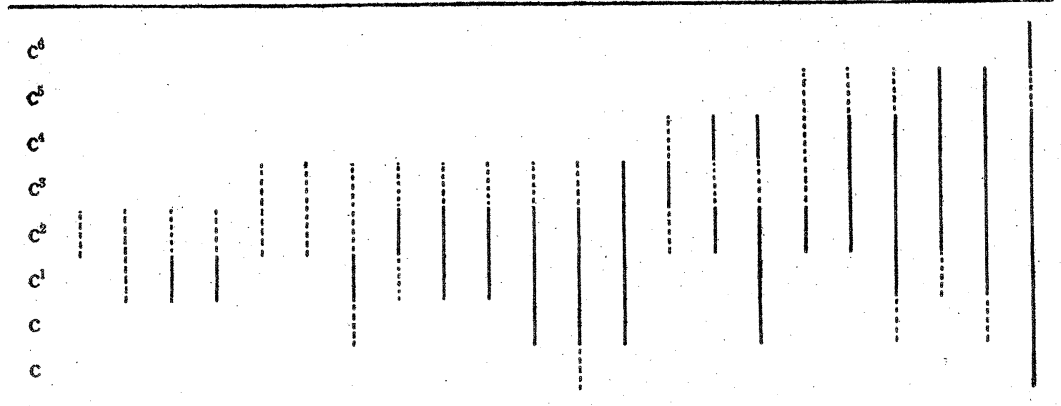

あり,點線は其以下で $40 \%$ 以上の殘聽を有するものである。左から右へ移るにつれて， より高い昔迄聞える者の順に配列されてるるが，高音域の等しいものでは，高卑に残㯖 度の大なる者程，右方に配置されてふる。かく高音域をより多く重䤄寸る所以は：之が 音聲の聽取にとつて一層重大であると思はれるからで，後の圖も皆此の配列によつて描

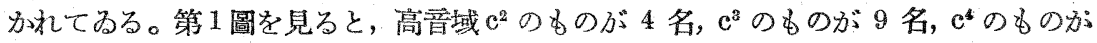
3 名, $\mathrm{c}^{5}$ のものが 5 名, $\mathrm{c}^{6}$ のものが 1 名である。さて之等のものが如何に異つて言 葉を聽取するであららかと云ふ間題である。

\section{III 賔 驗 $\mathrm{Ba}$}

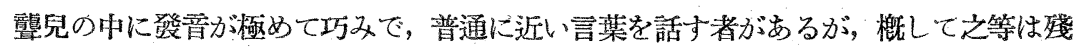
聽の著しいものに多い。然るに其等においてすら，未だ何等か異樣な感じを與へる場合 が多いが，其の原因は言葉の調子において不完全なるが爲である。言葉の全體の調子は 勿論であるが,より小さな塊りに沏ける, そして比較的固定的な音調, 所謂てクセント 
も，全く缺如してるるか，特異の誤つたものである。之は元より聽覺機能の缺損又は萎 縮に起因するが,彼等は之を果して如何なる程度まで聽取することが出來るであららか。 之を先づ第一の問題としたのである。

之に對してはなるべく多くの單語について考察したいし，更により長い句や文の調子 についても實驗を試みたいが，今の場合は，二音節で同音を含み，且つアクセントを異 にする 5 種 10 語を選んだ。郎ち

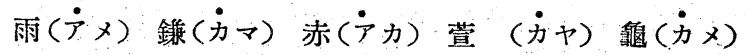

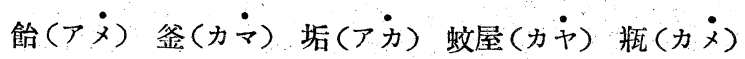

中寸迄もなく上段のるのは調子が下降的で，上中型と呼ばれるが，下段のものでは後 の音節がより高く，下中型と呼ばれるものである。或は後者には二音節語の殘りの一つ の型，下上型のむのがあるかも知れれ。併しその吟味は此處では必要なく，唯上段の語 と下段の語が同昔にしてアクセントを異にすることが保證されつば充分である。

さて之等一組宛の同音晎調語は一枚の紙に相並んで略畫によつて表はされてるる。實 驗者は之を被驗者の前に捛いて觀察せしめ，同時に試驗すべき耳の側 $15 \mathrm{~cm}$ の所でそ の語を發音し傾聽せしめる。その高さ及び强さは全く嚴番にではないが，略々一定して 登昔することに努めた。先づ普通の會話の時の音調である。

此の聽取の實驗は，練㤫と試しの二過程を含んでるる。練習の時は實驗者は發昔と共 に其に相當する繪を指さして，今の語は之であることを示す。試しの場合は發音につい で，其が何であるかを被驗者に指さっしめるのである。練劦及び試し（下に線のあるす の)の順序は次の如くでまる。

雨雨飴飴 雨雨飴飴 雨雨飴飴 雨雨飴飴, 雨飴 雨餂餂雨 雨飴 餂飴雨雨 雨飴 飴雨雨飴 雨飴 雨飴雨飴

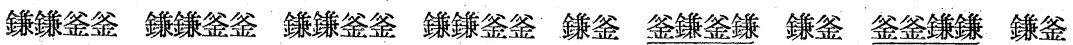
釜鎌鏣釜 鎌釜 錚釜鎌釜

赤赤垢垢 赤赤垢垢 赤赤垢垢 赤赫垢 赫 赤垢告赤 赤垢 垢垢赤赤 赤垢 哣赤赤垢 赤垢 赤垢赤垢

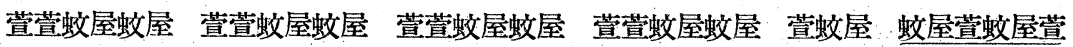

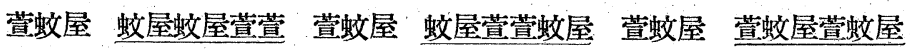

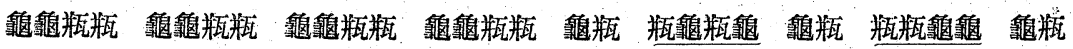

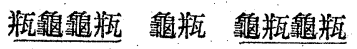

此の實驗の結果は第 2 圖に示されてるる。圖の數字は適合の率を示す。二語の中一語 を指摘するのであるから，でたらめの場合です50 パーセントの附近にあるおけである。 それ故實際の聽取の成績としては 50 の所が 0 の線となるべきであらう。被驗者は第 
第 2 圖

Wt. Kw. Kz, Kd. Ok, Jy. Kzm.Kr. Bt.Kdm.Mm.Fz. Nk. Ym. Nz. Tk. It.Ymg. Hr.Ymz.Ith. Iz.

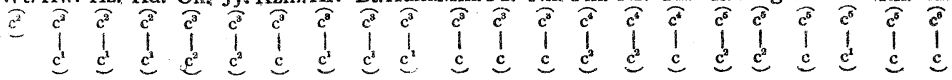

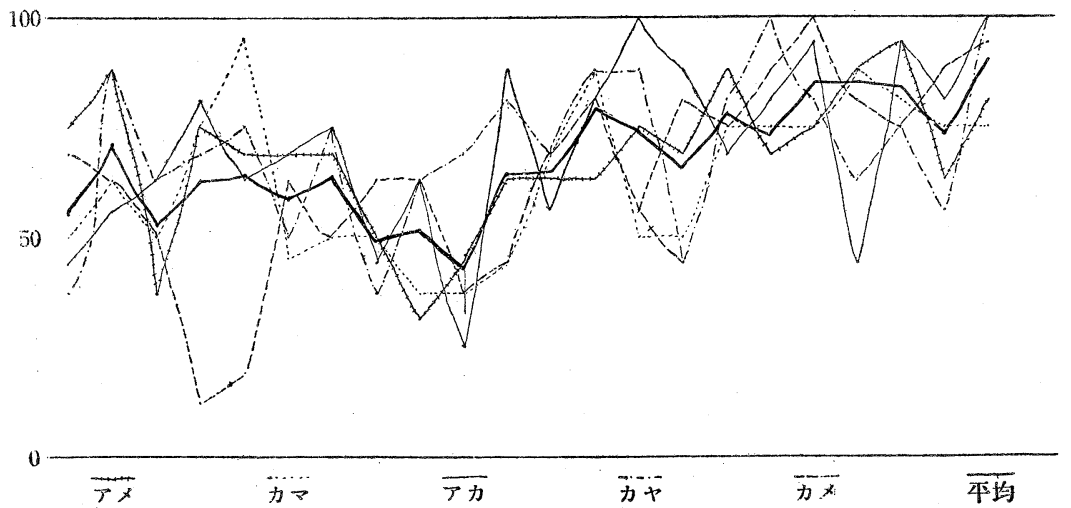

1 圖と全く同じに高音域の高いもの程，在方に配列されてるる。

此の圖を見ると語により又個人により，極めて樣々な聽取を行つてるる。件し之から 一般に何の語が他のものより聽取がより容易であるとか，より困醮であるとかを定める ことは早計であらら。唯すべての語の平均によつて，各個人の浇聽を考察することは可 能と思はれるし，其が此の賽驗の目的でもある。適合率の70\%位迄はでたらめとも思 はれるが，其以上になればアクセントの區別が相當に把挃出來たと見られないことはな い。今 $70 \%$ 以上の迎合率の者を見ると, Kw., Nk., Ym., Tk., It., Ymg., Hr., Ymz,Ith., Iz. 等である。此の中 Kw., Nk. 岁除いたすべてのものは, 2A Audiometer の檢查にて殘㯖の高音域が， $\mathrm{c}^{4}$ 以上にあるものである。反對に $\mathrm{c}^{4}$ 以上に高音域を有す るもの 9 名中 1 名の久が，本實驗に虬て $70 \%$ 以下の適合率を示したのであつた。 此の兩方面より，上記の語のアクセントを識別するが䉆には， $\mathrm{c}^{4}$ 上たに殘聽の高音域を 有しなけ狄ばならないことが推論されるのである。他面において，アクセントが基意の みの變化とも考へられるので， $\mathrm{c}^{1}$ から $\mathrm{c}^{2}$ の音域に殘聽があればよいやらに思はれるが，

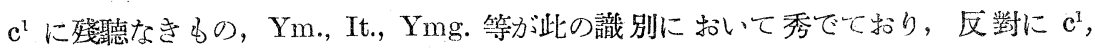
$\mathrm{c}^{2}$ に殘聽女る上記以外の多くのものが，此の把握が困難であることを示してるる點よ り,アクセントの認知に必要なる殘聽の音域は愈々以て $\mathrm{c}^{4}$ の附近でするやらに推測さ れるので女る。 


\section{IV 賽 驗 Bb}

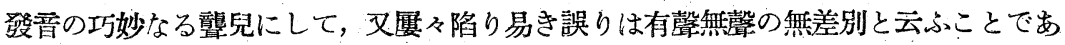

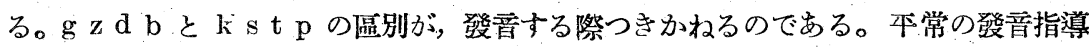
に當つては主として眼の㗢を以てする第, 馨帶の振動の有無をも觀取せしめることは困 難である。時には喉に手を觸れて感知せしめることはむるが，常に此の手段に賴るわけ にはいかない。從つて，此の混同が結果するのは當然である。併し或程度の殘聽を有す 者には，耳を通して此の識別が出來ないであららか，次は此の問題である。

之を調べる䉆には，語の調子が全く同じやうで，唯或音が有馨と無聲の違ひを有する 語を 5 組選んだ。其は次の 10 語である。

郎ち鑵(カン) 御篻(ミス) 系 (イト) 麵䴬(パン) 尺(サシ)

倠(ガン) 水 (ミッ゙) 井戶(年ド) 盤 (バン) 题(サジ)

之等上下一組宛の語は，一枚の紙に略畫で表されてるる。之を用ひて行ら實驗の手續き は，アクセントの場合と全く同樣であるから，此處には再述しない。唯練晢及び試しの 順序は前と稍々異つて次の通りである。

鑵鑵雁雁 鑵雁 鑵鑵雁雁 鑵雁 鑵鑵雁雁 鑵雁 鑵雁雄鑵 鑵雁 雁雁鑵鑵 鑵 难 倠鑵鑵雁 鑵雁 鑵雁鑵雁

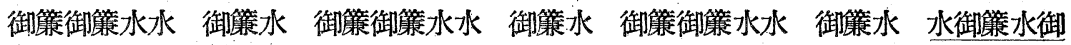

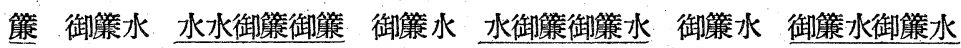

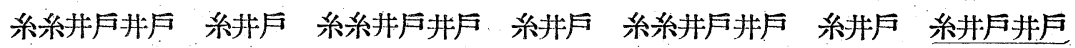

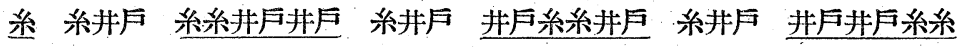

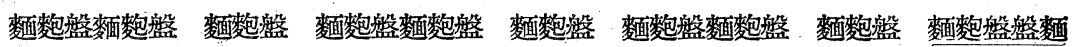

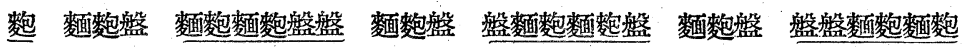

尺尺匙匙 尺题 尺尺匙题 尺题 尺尺匙匙 尺匙 尺匙题尺 尺题 匙题尺尺 尺 题 题尺尺题 尺题 尺尺匙题

アクセントの場合にあつては，識別の働きが個人によつて大いに巽つてるたが，此の

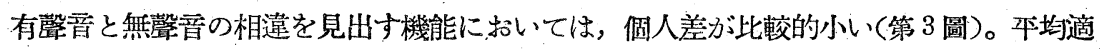
合率の最も高いものでも $75 \%$ である。そして $70 \%$ 以上のものは僅に 6 名に過ぎな い。此の中 4 名が $\mathrm{c}^{4}$ 及び其より高い所まで聞え，他の 2 名の高㱏域は $\mathrm{c}^{3}$ 又は $\mathrm{c}^{2}$ で ある。これから; 高看域 $\mathrm{c}^{4}$ 以上のるのは, 其以下のものに比べて僅かにすぐれててる やうであるが，其の優劣の差は極めて微かであると云へる。此の結果においては又, 各 個人が得た 5 組の語に對する適合率が, 前の場合より, より少く一致してるる。其丈確

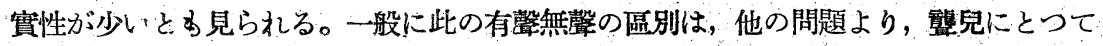




\section{第 3 圖}

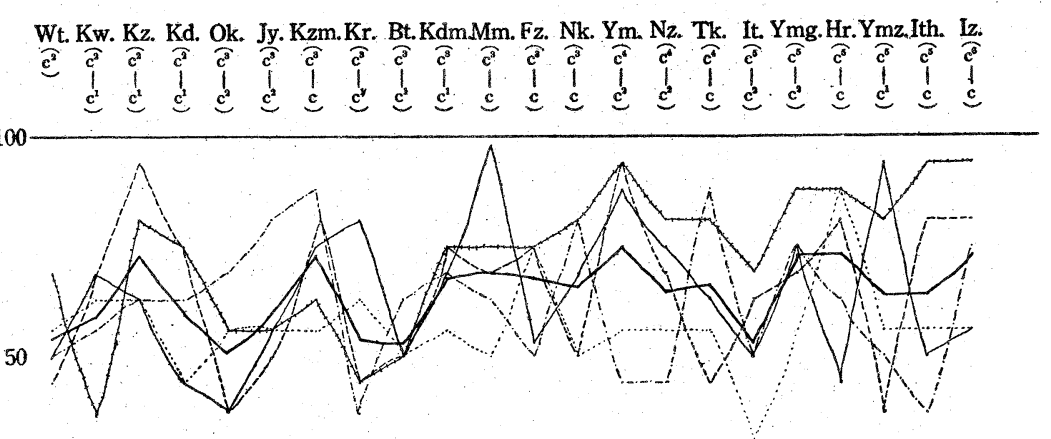

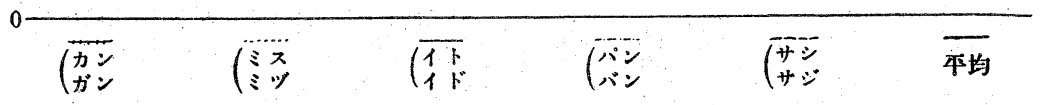

より多く困難であることが認められた。

\section{V 實 : 驗 Bc}

殘聽による音辟の聽取を檢出する篇の第三の問題は，s の系統の害と $\mathrm{t}$ の系統の音と の區別である。襲圌の發至中に，アリマチタ，アリマッ，チェンチエー等は，日常極め て愿々聞く所である。併し正常兒においても發府機能の未發達の場合に同樣の誤りが行 は机てるることも，又日常愿々經驗する所である。かくて tより sの方がより進步し た，又より困難な舀と考へられるが，其等の何れにも屬さない中間の害もある。郎ちチ

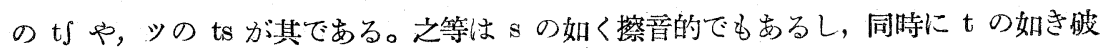

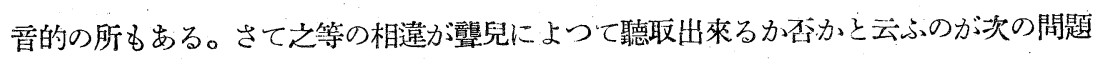
である。

之に對して選んだ語は次の 10 語である。

金(カサ) 牛(ウシ) 砂(スナ) 汽車(キシャ) 一升(イッショウ)

屃（カタ）家(ウチ) 綱(ツナ) 北（キタ） 一町(イッチャウ)

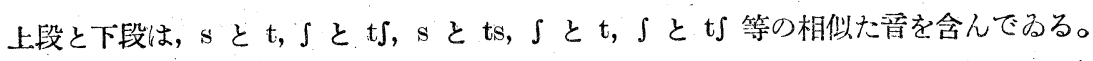
發音の順序やその他の實驗方法は, 前二問題の場合と局樣であるから此處には省略す る。

之の結果は第 4 圖に表はされてるる。之を見ると, 各組の邀合率の開きは, 第二の問 


\section{第 4 圖}

Wt. Kw. Kz. Kd. Ok. Jy. Kzm. Kr. Bt. Kdm.Mm. Fz. Nk. Ym. Nz. Tk. It. Ymg.Hr.Ymz.Ith. Iz.

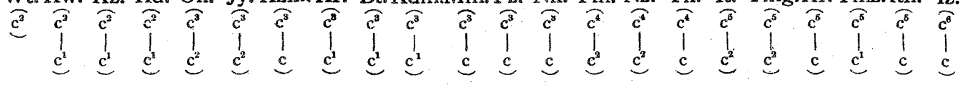

100

50

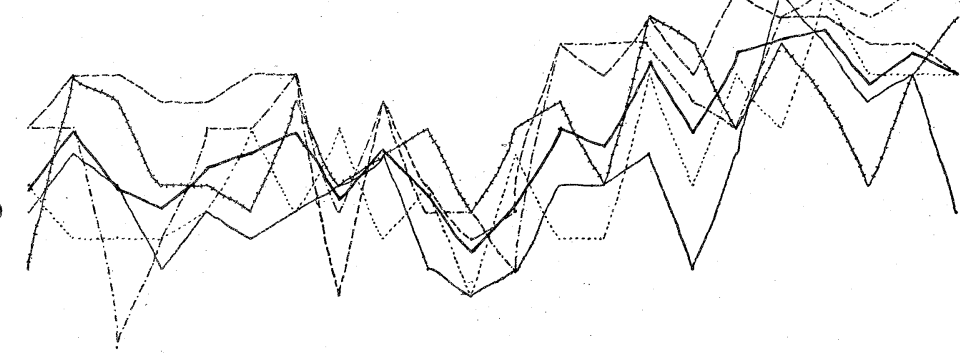

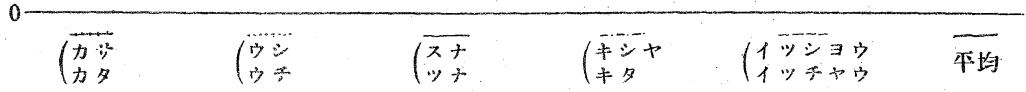

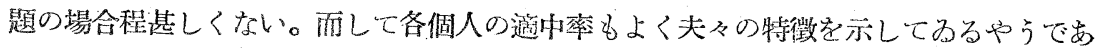

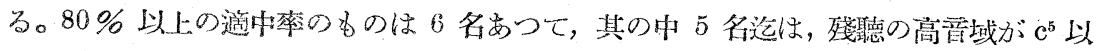

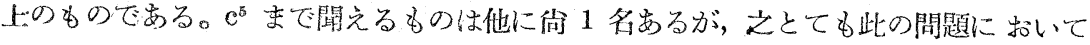

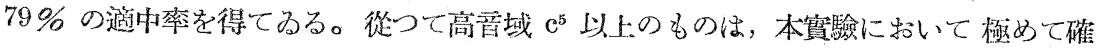

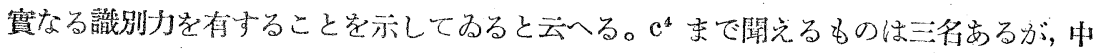
一名が $84 \%$ の適中率定得てるるが，他の二名は70\%に当達してるない。此の事か

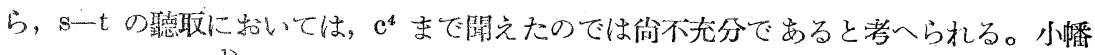
博士の賽驗の結果では，サ行の $\int$ 振動數は每秒 3700 , 夕行の t $\int か ゙ 3500$, ts が 3700 ,

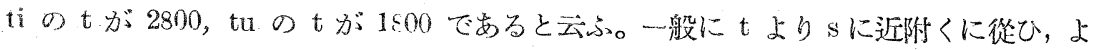

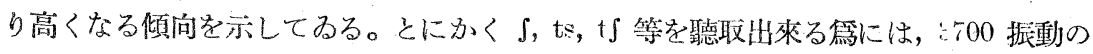

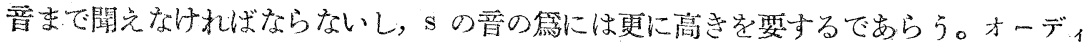
オメーターで $\mathrm{c}^{4}$ は 9018 振動, $\mathrm{c}^{5}$ が 4096 振動であるから, $\mathrm{c}^{4}$ では不充分, $\mathrm{c}^{5}$ まで

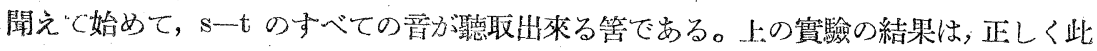
の推論と一致する所でする。即ち残聽の高舀域 $\mathrm{c}^{5}$ 以上のものが，本實驗において，德 取の著しい確實性を゙示したのであつた。 


\section{VI 實 驗 $\mathrm{Bd}$}

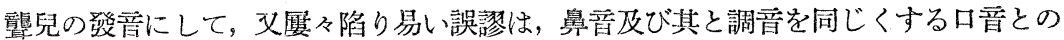
混同である。即ち $\mathrm{d}(\mathrm{t})-\mathrm{n}, \mathrm{b}(\mathrm{p})-\mathrm{m}, \mathrm{g}(\mathrm{k})$ - $\mathrm{n}$ の間に跲別のつき難いことである。ユ キマシタをユキバシタ,アリマセンをアリバセン等と云ふ。吾々は軟口蓋の運動を直接 意識することが出來ないが，唯鼻腔が共鳴するための振動と害とによつて間接に知覺し 得るのである。䲞兒においては耳によつて之を會得することが出來ないから，指を鼻頭 に當てて感知すると云ら手段で此の發音を學甭する。湖し之のみでは元より不完全とな らざるを得ない。從つて周番の等しい鼻音と口番が互に混同される次第である。果して 殘聽ある䆍兒にも之等の區別が聽取出來ないであららか，之が第四の問題である。

そに對しては次の5組の語を選んだ。即ち

$$
\begin{aligned}
& \text { 旗 (ハタ） バット指(ユビ) 烏賊(イカ) 山車(ダシ) } \\
& \text { 花(ハナ) マット月(ユミ) 毛埌(イガ) 梨（ナシ） }
\end{aligned}
$$

の 10 語である。下列は鼻音を含み，上列は其に對應する口昔を含んでるる。實驗の方 法は他の場合と同樣であるから雨記することを省略する。

\section{第 5 圖}

Wt. Kw. Kz. Kd. Ok. Jy. Kzm.Kr. Bt.Kdm.Mm. Fz. Nk. Ym. Nz. Tk. It. Ymg.Hr.Ymz. Ith. Iz.
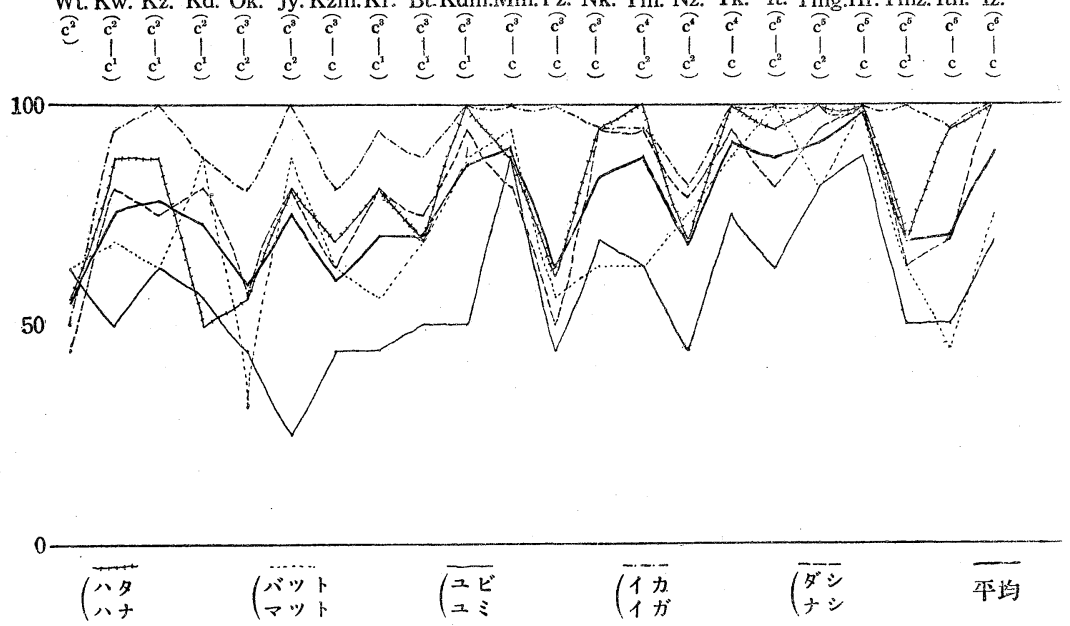

結果は第 5 圖に示されてるる。此の閶題は一般によく聽取されてるる, むしろよく區 別され過ぎた傾向が見える。何となれい゙殘聽の餘り多くないと思はれる被驗都にも，相 當に確實さを以て識別されてるるからである。或は音以外に氣息の壓の相違等が，此の 
識別の過程に關與してるるのではないかとも考へられる。尤も豫め發音者と被驗者の耳

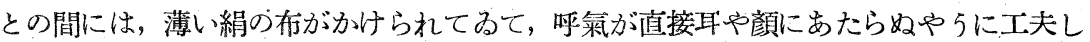
てはあつた。之は他の問題の場合もさ5であつた。併し之で完全に防がれたとは断言す ることが出來ない。イカとイガ等の區別は却々困難と思はれるのに，何れの襲兒にもよ く把握されでる。最も困難なるものはュビとュミとであつた。ビ及びミが，i の弱い 母音と結合してるて不明膫な急であら5。バットとマットとは次に困難なものであつた。 之は後牛の母音が a であつて勢力は大きいが，言㷊の意味が明確に銘記しにくかつた 䉆であららか。なるべく兒童の生活に近い語を選しだのであるが，之は適切でなかつた か子知れし好。併しこっでは之等の語材の難易は稌り問題にする積りはなく, 要點は他に ある。郎ち之等五組の語が，個人によつて如何に暴つて識別されるかと云ら事である。 しかるに此の問題では上記つ如く, 全禮によく把握され過ぎてるるわけである。併し其 でも平均適中率を見万と，右方に行く程，郎ち高畄域の高いもの程多少優れてみるゃち に思は机る。

\section{VII 實 驗 Be}

次の問題は前の四つの場合と稍々筫り，單語でなく單一なる五つつ母音が如何に識別 されるかと云ふ事である。之には㯖取の練習を課することなく，直ちに試しを行つた。 五つの母音は䆍兒にとつて最も早くから發音練習をなさしめられるるのであつて，若し も殘聽の有效なるものがあれば，其の間に既に聞き分ける働きを獲得してるる䈏だから である。各母音は 10 回宛發音されるが，其の順序は次のやうである。

\begin{tabular}{|c|c|c|c|}
\hline 才 & I. & $\boldsymbol{P}$ & ウ \\
\hline & ウ & 1 & $\boldsymbol{\gamma}$ \\
\hline & オ & ウ & I \\
\hline & $>$ & t & $I$. \\
\hline & t & 1 & I \\
\hline
\end{tabular}

$\begin{array}{lllll}\text { エ } & \text { ア } & \text { オ } \\ \text { エ } & イ & \text { ウ } & \text { オ } \\ \text { エ } & \text { ウ } & \text { オ } & \text { ア } \\ \text { ウ オ } & \text { イ } & \text { エ } & \text { ア } \\ \text { ア イ エ } & \text { ウ }\end{array}$

被驗者の前には，紙に无つこ假名が書いてあり，聽く每にその何れであるか龙指さす のである。

此の結果住第6 圖に示されでるる。之を見ると五つの母音は各人において，同じ樣な 成績で聽取されてはるない。其でも他の場合と比べて最も一致してるる方である。先づ 適中率の本均について見ると，90\% 上上のものが 4 名ある。何れも殘㯖の最高音が $\mathrm{c}^{5}$ 以上である。尚 $\mathrm{c}^{5}$ 以上の聞えるものが 2 名あるが，其の中の 1 名は $85 \%$ ，他の 1 名 は $76 \%$ の適中率を得てるる。一般に $\mathrm{c}^{5}$ 以上の聞えるるのは, 此の母音の識別に捛い て最も確實であると云へるであらら。次に $\mathrm{c}^{4}$ に高昔域のあるものは 3 名あるが，1名 
第 6 圖

Wt. Kw. Kz. Kd. Ok. Jy. Kzm. Kr. Bt. Kdm.Mm.Fz. Nk. Ym. Nz. Tk. It. Ymg.Hr. Ymz.Ith. Iz.

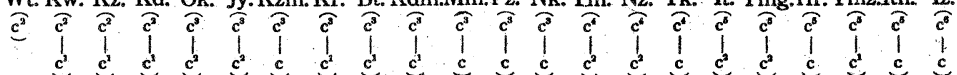

100

50
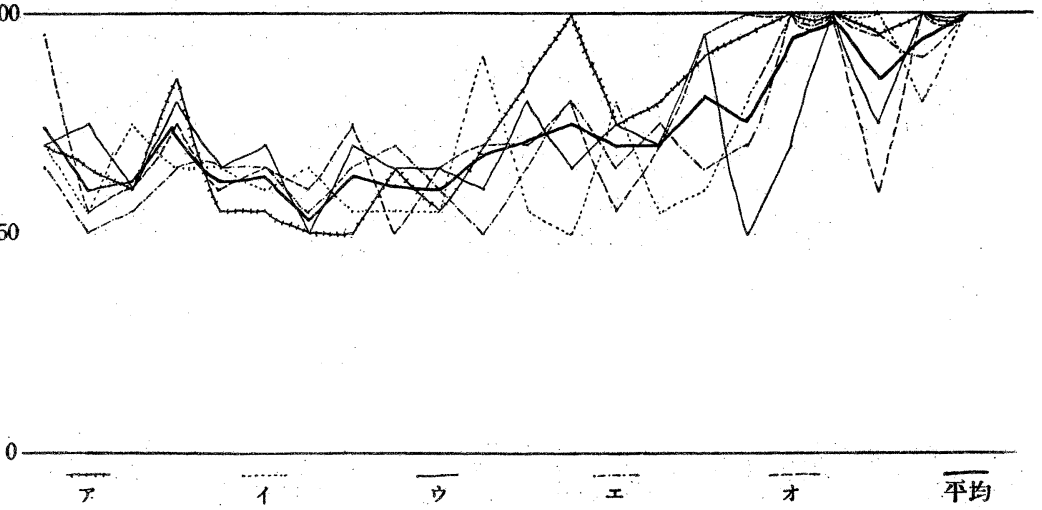

は $81 \%$ 他の 2 名も $70 \%$ の適中率を示してるる。しかるに $\mathrm{c}^{3}$ まで聞えるものは 9 名あつて，適中率 $70 \%$ 以上のものは僅かにっ名に過ぎない。故に $\mathrm{c}^{4}$ までの殘聽の

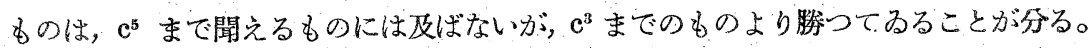
かくて全體として，高音域が $\mathrm{c}^{6} \mathrm{c}^{5} \mathrm{c}^{4} \mathrm{c}^{3}$ と下るにつ玌て，母音識別の確實性も漸次下 降してゆくことが認められるのである。しからば $\mathrm{c}^{5}$ のものと $\mathrm{c}^{4} \mathrm{c}^{3}$ のものとでは如何 なる點动黑るかと云へば， $\mathrm{c}^{4}$ 及び $\mathrm{c}^{3}$ のbのは概してイ及びェの聽取において $\mathrm{c}^{5}$ の のに少つてるるやうに見える。小幡博士の實驗では，イエの第二又は第三の特徵音域吕 3000 振動以上であつて，しかも强いものである。殘㯖 $\mathrm{c}^{3}$ や $\mathrm{c}^{4}$ までのあは之を㯖取 出來ないから，イゃエの特徵を把へ得ないことは，蓋し當然の事である。オウ等る亦一 般に劣つてるる。

\section{VIII 結 語}

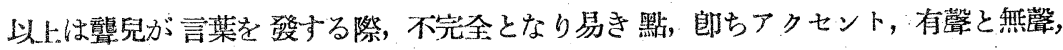
サ行䆨とタ行音，鼻音と口音，五種の母音等の問題につき，壟兒が如何に識別聽取し得 るかを考察したのであつた。之等の點は音馨語の重要なる性質をも代表するるのと考 へられるから，或程度まで一般的な壟兒の言葉の聽取機能の考察と見做される。而して 以上は各問題を別個に取报つたが，次に之を概觀すること〉する。

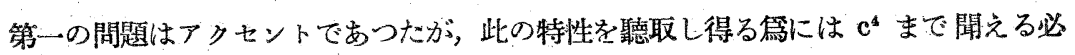

1）小幡重一實驗言㗽學 192 頁上り。 


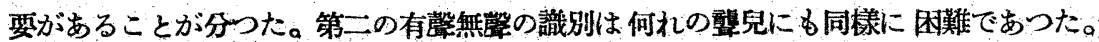

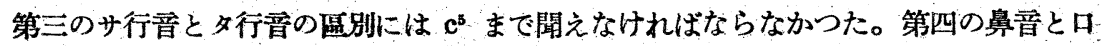
音の問題では，同じ樣な程度に聽取されてるて，殘㯖との關係が不明である。第五は母 音の區別であるが，之には $\mathrm{c}^{5}$ 以上少くとも $\mathrm{c}^{4}$ までは聞えなければならないことが分 つた。かく上の五つの音馨語の特性を把暒出來る篇には $\mathrm{c}^{5}$ まで，少くとも $\mathrm{c}^{4}$ まで聞 える必要のあることが明になつた。第 7 圖には夫々の䦗題の實驗の結果の本均が示さ

\section{第 7 圖}
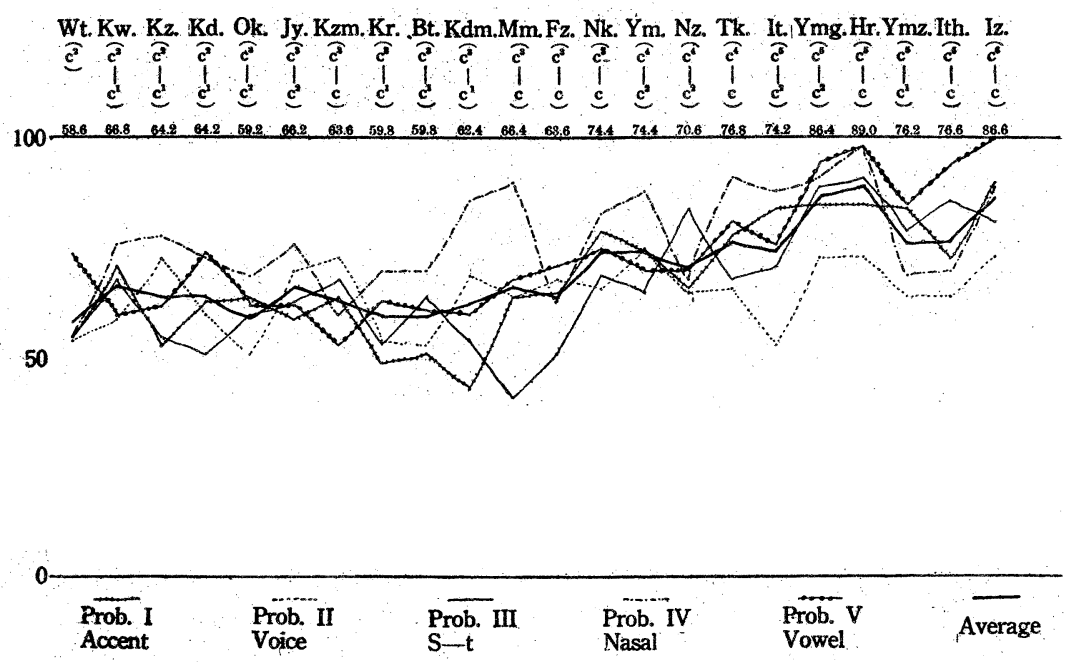

れてるる。更にその五つを本均すると，太い黑線のや5になる。之を見ると滴中率 75 $\%$ 以上のるのが 6 名むるが，其の中 5 名は $\mathrm{c}^{5}$ まで聞えるものである。そして残り 1 名は $\mathrm{c}^{4}$ まで聞えるものである。此の他今 1 人 $\mathrm{c}^{5}$ を高音域と寸るむのがあるが, 之と

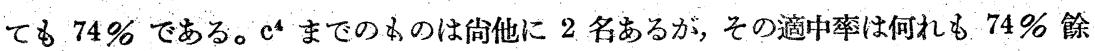
りである。 $\mathrm{c}^{3}$ までのものはすべて之汔に達してるない。かくて $\mathrm{c}^{4}$ 以上の聞えるるのに して始めて $75 \%$ 以上又は其に近い成績を得てるるわけである。本實驗の結果, 適中 率 $75 \%$ は實際の聽取能力 $50 \%$ に相當する。とにかく全體の本均から見ても $\mathrm{c}^{4}, \mathrm{c}^{5}$ の 聞える壟兒では，普馨の聽取が他の者に比して著しく確實性を增してるることか認めら れるのである。

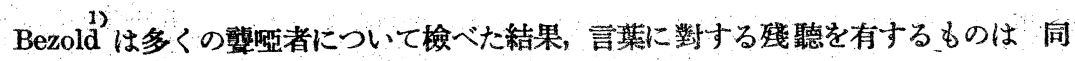

1) Denker, A. und W. Albrecht: Lehrbuch der Krankheiten des Ohres und der Luftwege S, 215 \& $\$$ 
時に常に $\mathrm{b}^{1}-\mathrm{g}^{2}$ の單純急を聞き得ることを確め，兩者の間に緊密の關係のあることを 主張したのであつた。此の場合言葉の聽取の篇の目標を如何なる點に抽たのか不明で あるが，上記の如き國語の五つの目標によつて行つた本實驗の關する限り，其の結果は Bezold の見解と一致しなかつた。郎ち Bezoldにおいては言葉の聽取の䉆には $\mathrm{b}^{1}$ $\mathrm{g}^{2}$ の殘聽を必要とすると云ふのであるが，本質驗の結論では $\mathrm{c}^{4}, \mathrm{c}^{5}$ の殘聽がより重要 であると云らのである。而して後者は近年著しく盛になつた昔聲の物理學的の實驗の結

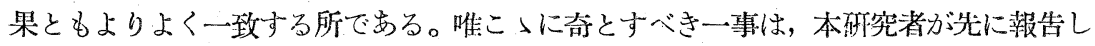
た如く，殘聽の多くのものが $\mathrm{c}^{1}-\mathrm{c}^{2}$ を起點として㴬次高低网方向に擴がつて殘存する 傾向のあると云ふ事の詨明の篇には Bezold の主張がより都合のよいと云ふことであ る。即ち個體發生的にも種族發生的にも, 吾々の聽覺を最も常に刺皒する所のものは音 馨であるが，其が $\mathrm{b}^{1}-\mathrm{g}^{2}$ の音域を占めて居るとすれば，此の部分がより多く保護され 又は發達やしめられることが極めて當然の事と考へら札るからでる。不弆にして Bezold の主張は, 本實驗の結果之も一致しないし, 一般に今日の諸方面の破究にも不 都合になつて來てるる。作しこうに考へられることは, Bezold の言葉又は番聲の㯖取 と云ふ概念が比較的素朴であつて, 唯聲が聞えると云ふ程度のものであるかも知れし奴 とである。さうす扎ば人間の言葉が末本げ今日の如く分化しないで原始的な形のものを對

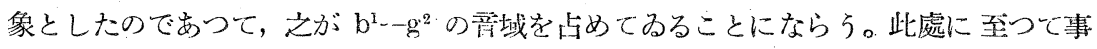

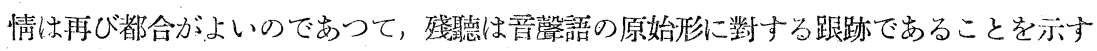

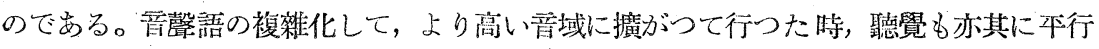
して進化して行つたものと考へら狄る。其が種々の障害炎受ける場合色々な程度又は段 階に少いて自己を保存するものであらら。かくして原始語と交化語と云ら對立を想定し

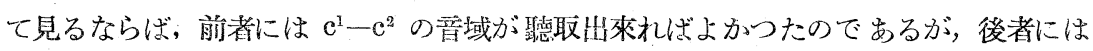

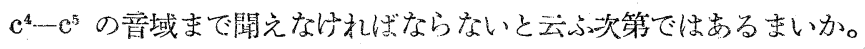

H. Fletcher は言葉を認知する䈧の害域は 500-2000 振動であるとし, 言葉に對す る殘聽を知る簡便なる方法として $\mathrm{e}^{2}, \mathrm{c}^{3}, \mathrm{c}^{4}$ のオーディオメータ一測定の結果を平均

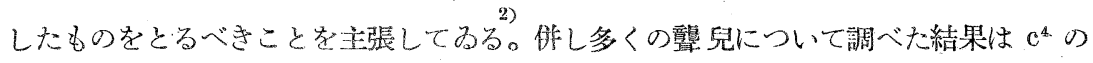
聞えるものは大部分 $\mathrm{c}^{3}$ 及び $\mathrm{c}^{\mathrm{z}}$ まで聞えることが分つた。之は本實驗に用ひた被驗者

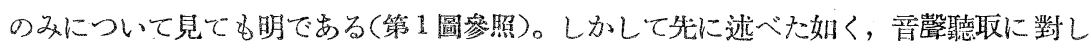
て一曆重要なのは $\mathrm{c}^{4}$ 及び其より高い音であるから，單純なる暗による檢查によつて言

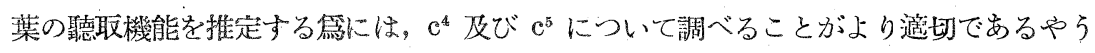
に思はれる。之等の音域は一般に輜兒にとつて聞え難いのであつて，比較的少數のむの

1) 鹳青心理䃑究 IX, 10 .

2) Fletcher, H.: Speech and hearing. p. 220 より。 
が之を聽取出來るのである。併し一度此處に残聽が檢出されつば，其の利用性は甚だ大 きいのである。敎育の實際問題としてはかつる残聽のものは, 難聽兒又は準䧼聽兒とし て特別の學級に編入せられ，少くとも特別の取拆ひを受くべきものである。併しその目 的は，必ずしも耳の外よつて日常の言語生活を營ましめることではなく，之によつて

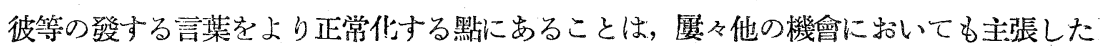
所であつた。 
(From the Psychological Institute, Tokyo Deaf and Dumb School)

\title{
On the Deaf Children's Hearing of Speech Sounds
}

by

\author{
K. Ishii
}

It is the purpose of this work to compare the two abilities of deaf children to hear pure tones and to hear speech sounds. The residual hearing for pure tones was examined with 2-A audiometer manufactured by Western Electric Co. in U.S. A. which gives eight pure tones; C, c, c, ${ }^{1} \mathrm{c}^{2}, \mathrm{c}^{3}, \mathrm{c}^{4}, \mathrm{c}^{5}, \mathrm{c}^{6}$.

The subjects were twenty two children who belong to the middle and primary course of the Tokyo Deaf and Dumb School. One of them was ascertained to be able to hear all eight tones of the audiometer, from $\mathrm{C}$ to $\mathrm{c}^{6}$, while another could hear only one tone $c^{2}$. The rest of all children were to be ranked gradually between above mentioned two children according their own hearing.

To test the ability to hear speech sounds next five characteristics were selected which seem to be most difficult for the deaf to pronounce and at the same time seem to represent most important qualities of speech structures. The characteristics selected were accent, voice and voiceless, sound -s and sound-t, nasal and unnasal and five Japanese vowels. For any one of these qualities except vowels were selected five series of paired words, for example ame (rain) and amé (wheatgluten) in accent, ito (string) and $i d o$ (well) in voice and voiceless etc., which were different on the problematic point and almost similar on the other point, namely as the whole structure.

Every word was pronounced by a little louder and higher voice than in daily conversation in the distance of fifteen $\mathrm{cm}$. from the ear of the patient from which the expiration of the speaker was kept away with a cloth of silk. The ability to hear every word was tested after several trials of the preliminary exercise.

The results were as follows; (1) to recognize accent it was necessary to be audible upto $\mathrm{c}^{4}$ from lower tones, (2) the difference of voice and voiceless seemed to be most difficult to catch for all children, (3) to discriminate sound $-\mathrm{s}$ and -t necessitated the rest of hearing for $\mathrm{c}^{5}$ and lower tones, (4) nasal and unnasal were easiest for all and individual pecurialities were not observed, (5) five vowels were completely heard only by the child who has the audibility for $\mathrm{c}^{5}$, but they were heard too by the child able for $c^{4}$, though with less certainty.

F. Bezold insisted on the ground of the investigation in the abundance of deaf and dumbs that the rest of hearing necessary to hear speech sounds is the one 
for $c^{2}$. H. Fletcher too measured the audibilities of the deaf children in various methods and considered it to be most suitable to take up three tones $\mathrm{c}^{2}, \mathrm{c}^{3}, \mathrm{c}^{4}$ as indispensable for hearing speech.

However as far as this experiment concerns, it seems to me that $c^{4}$ and $c^{5}$ are more important. And as I have concluded in my earlier report, $c^{2}$ is the center to preserve itself of the residual hearing and spreads higher and lower step by step from that point. Therefore the child who is capable to hear $\mathrm{c}^{4}$ and $\mathrm{c}^{5}$, without saying can hear $\mathrm{c}^{2}$, too. Then the simplest way to see the audibility for speech is to investigate the rest of hearing by $c^{4}$ and $c^{5}$. By this shortest way we can find as soon as possible the hearing abilities of deaf children and utilize them to instruct the pronounciation or speaking. This is a suggestion towards the education of the deaf, obtained from this work.

(From the Psychological Institute, Tokyo Kôtò Gakkô)

\section{Contributions to the Study of Psycho-physical Induction}

VIII. The Fundamental Law of Psycho-physical Induction

by

\section{T. Obonaj}

Problem: In the fourth of a series of papers the writer has reported an in. vestigation upon the general law of psycho-physical induction. In connection with this problem a further detailed analysis will be made in the present article.

Now, the outside distances of the diagram A, B, C, etc. in Fig. 7, although actually equal, appear to be of unequal length.

In the following investigation, I have sought to determine a relation between the

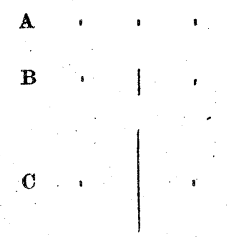

etc. amount of the illusion and the size of the inner interpolated stimulus which varies from zero to a marked degree of length.

In making the measurements, the stimulus diagram was observed at the distance where the outer dots of the diagram are just visible. (The size of each dot is $0.5 \mathrm{~mm}$. in breadth and $1 \mathrm{~mm}$. in height. The observer usually sat at a distance of 5 meters from the objects.)

Fig. 1 .

Results : Fig. 2 in Japanese text p. 454 shows a typical 